\title{
UNDERSTANDING MEDICAL TERMS
}




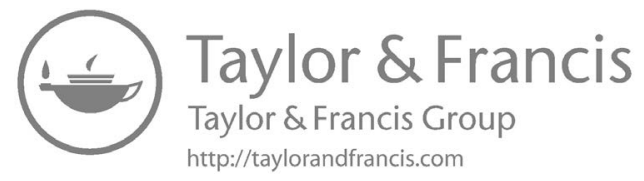




\section{SECOND EDITION \\ UNDERSTANDING \\ MEDICAL TERMS \\ A Guide for Pharmacy Practice}

\section{Walter F. Stanaszek, Ph.D. R.Ph.}

Health Care Consultants, Inc.

Pharmacy Practice and Education

Norman, Oklahoma

Mary J. Stanaszek, R.R.A.

Health Care Consultants, Inc.

Health Care Information

Norman, Oklahoma

\section{Robert J. Holt, M.A., R.Ph.}

Health Care Consultants, Inc.

Community Pharmacy and Administration

Oklahoma City, Oklahoma

\section{Steven Strauss, Ph.D., R.Ph.}

Professor of Pharmacy Administration

Arnold \& Marie Schwartz College of Pharmacy and Health Sciences

Long Island University

Brooklyn, New York

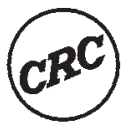

CRC Press

Taylor \& Francis Group

Boca Raton London New York

CRC Press is an imprint of the

Taylor \& Francis Group, an informa business 
Published in 1998 by

CRC Press

Taylor \& Francis Group

6000 Broken Sound Parkway NW, Suite 300

Boca Raton, FL 33487-2742

(C) 1998 by Taylor \& Francis Group, LLC

CRC Press is an imprint of Taylor \& Francis Group

No claim to original U.S. Government works

1098765

International Standard Book Number-10: 1-56676-595-1

International Standard Book Number-13: 978-1-56676-595-4

Library of Congress catalog number: 98-85738

This book contains information obtained from authentic and highly regarded sources. Reprinted material is quoted with permission, and sources are indicated. A wide variety of references are listed. Reasonable efforts have been made to publish reliable data and information, but the author and the publisher cannot assume responsibility for the validity of all materials or for the consequences of their use.

No part of this book may be reprinted, reproduced, transmitted, or utilized in any form by any electronic, mechanical, or other means, now known or hereafter invented, including photocopying, microfilming, and recording, or in any information storage or retrieval system, without written permission from the publishers.

Trademark Notice: Product or corporate names may be trademarks or registered trademarks, and are used only for identification and explanation without intent to infringe.

\section{Library of Congress Cataloging-in-Publication Data}

Catalog record is available from the Library of Congress

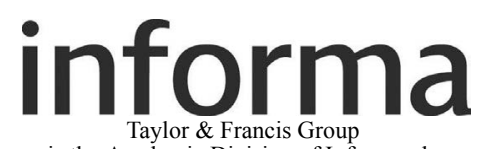

is the Academic Division of Informa plc.
Visit the Taylor \& Francis Web site at http://www.taylorandfrancis.com

and the CRC Press Web site at http://www.crcpress.com 
PREFACE TO THE SECOND EDITION

PART I: THE BASIS OF MEDICAL TERMINOLOGY

Chapter 1 - Fundamentals of Medical Terms 3

$\begin{array}{lr}\text { Chapter } 2 \text { - The Health Care System Structure } & 19\end{array}$

Chapter 3 - Translating the Medical Record 25

Chapter 4 - Abbreviations, Eponyms, and Lay Terms 41

Chapter 5 - The Cardiovascular System and Its Disorders 61

PART II: THERAPEUTIC TERMINOLOGY 59

Chapter 6 - The Digestive (Gastrointestinal) System and Its Disorders $\quad 79$

Chapter 7 - The Musculoskeletal System and Its Disorders 97

Chapter 8 - The Integumentary (Dermatologic) System and Its Disorders 119

Chapter 9 - The Respiratory System and Its Disorders 129

Chapter 10 - The Reproductive System and Its Disorders 147

Chapter 11 - The Urinary System and Its Disorders 165

$\begin{array}{ll}\text { Chapter } 12 \text { - The Nervous System and Its Disorders } & 177\end{array}$

Chapter 13 - The Special Sense Organs and Their Disorders 193

$\begin{array}{ll}\text { Chapter } 14 \text { - Psychiatric Disorders } & 211\end{array}$

Chapter 15 - The Endocrine System and Its Disorders 225

Chapter 16 - The Hematologic System and Its Disorders 239

Chapter 17 - The Lymphatic/Immune System and Its Disorders 251

Chapter 18 - Oncology 263

Chapter 19 - Trauma and Poisoning 281

Chapter 20 - Nutritional Disorders/Alternative Medicine 289

$\begin{array}{ll}\text { Appendix A - Medical Abbreviations } & 303\end{array}$

Appendix B - Study Examinations $\quad 377$

$\begin{array}{ll}\text { Bibliography } & 401\end{array}$

$\begin{array}{ll}\text { Index } & 403\end{array}$ 


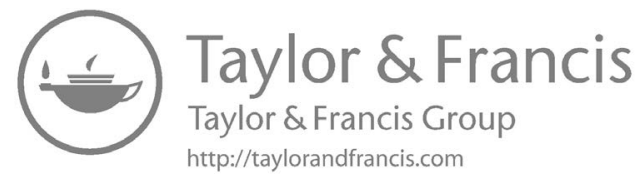


The need for a thorough understanding of medical terminology has not diminished in the least for pharmacists and other health care practitioners in the five years between the publication of the first edition of this book and this second edition. If anything, it has becomie greater. The pharmacy profession has further solidified its clinical role in patient care, and pharmacists are more entrenched than ever before in the role of counselor and advisor to both patients and practitioners alike. For more than a few pharmacists, what not long ago was an occasional question from a physician about appropriate drug therapy has become regular consultation concerning the interaction of drugs with the patient, his life, and the many other therapies he may be facing. Pharmacy chains, which not long ago installed glass walls to separate the pharmacist from customers, have asked technicians to count pills while pharmacists are in continuous contact with the patient.

Such practice changes have increased the demand for clinical knowledge among pharmacists, including a knowledge of medical terminology, and those demands have been passed on to the authors in preparation of the second edition of this book. While the role of the text is still to help pharmacists be more effective interpreters and counselors, some changes have been made in response to reader requests.

The most obvious changes were designed to make the book more useful as a reference when a specific need arises. It is still intended as a study tool, to be read from beginning to end in an organized learning sequence, but many readers found the need to return to these pages repeatedly over time to better understand terminology encountered in their daily professional lives. A complete index has been added, quickly allowing readers to find the discussion of medical terms they do not understand; many of the tables have been expanded to put more information at the readers' fingertips; and a table of common abbreviations has been added to each therapeutic chapter to give readers a more manageable amount of information at a time.

Otherwise, the text was expanded to include more recent terminology and more thorough explanations of medical terms. Medical practice and the entire health care system have changed, and the system terminology has changed with it. The National Institutes of Health has instituted an Office of Alternative Medicine, and the terminology of many alternative medical approaches is now included in this book. In short, the text is more complete for today's practitioner.

Many of the features of the first edition still remain. Although abbreviations are included in each chapter, the entire list is still included as Appendix A, allowing quick reference for unknown abbreviations. The text is still divided into two parts: the first four chapters cover the basis of medical terminology and provide an understanding of the components from which terms are formed; the second part examines more specific 
terminology as it relates to therapeutic categories. The figures are still included, simplifying anatomic terminology. And each chapter still includes a glossary with the definitions of major terms in the therapeutic category and a pronouncing glossary to aid in oral communication.

The philosophy underlying this book also has not changed. The text is still a learning tool for both practitioners and students. A continuing education manual is still available to help practitioners earn the appropriate credit for their study; self-tests are still included for each chapter, although they are now grouped together in Appendix B; the diagrams and the text are designed for clarity of understanding, rather than merely to compress the greatest mass of information into the smallest amount of space. In short, the authors have tried to make this book better serve the readers' needs. It is our sincere hope that you will think we succeeded. 
The study of medical terminology is integral to any study of the medical system. Like any other field, medicine has its own special language, and an understanding of the language is necessary for an understanding of the discipline. Knowledge of medical language identifies those who belong in the inner sanctum, the brotherhood of those trained in the medical arts. It serves to admit those with the knowledge and exclude those who do not possess it. In this way, medical terminology provides an air of mystery and a cloak of authority for those in the health professions. Secondly, this "hidden" language protects the medical community from the public by denying the patient an understanding of his condition and treatment. Diagnoses, procedures, and treatment modalities are referred to by esoteric names that the patient does not understand, perhaps helping physicians and other health professionals exercise authority over the patient. Although medical terminology may serve these functions, the patient does not necessarily benefit.

The most legitimate function of any lexicon should be to provide clarity and specificity to communication. Medical terminology serves that purpose. Since medical terms do not vary in meaning from one generation to another or from one community to another, they are extremely precise in their definitions and allow those in the health care community to converse with each other with exactitude. This exactitude, however, is lost to those who do not speak the language. Therefore, it is essential for those within the health care community, including pharmacists, to master the language of the discipline if they are to take part in medical decision-making processes.

Generally, pharmacists have a good understanding of the medical terminology they frequently encounter. As students progress in pharmacy school, their knowledge of terms is expanded by the study of anatomy, physiology, pathology, pharmacology, and therapeutics, as well as by their internships. This book can help pharmacy students systematize such knowledge and refine their communication skills. Thus, this book is intended in part for pharmacy students. By the time they graduate, however, most students have a broad base of understanding for common medical terminology. So why should a practicing pharmacist need a book like this?

Most pharmacists are unique in their communities. In the community practice setting, pharmacists constitute the initial access to the health care system for a large number of patients. In the hospital, pharmacists often counsel patients about medications and other therapies, and they turn their patients over to community practitioners after discharge for further counseling. Indeed, the typical pharmacist interacts with more patients in a given day than any other health care professional. Pharmacists are often asked by patients to make sense of "medical jargon" to help them understand the frightening system in which they are trapped. 
Additionally, the pharmacist must interact with the other health care providers. Clarifying orders, verifying medical necessity, evaluating the appropriate drug therapy in relation to other therapies and the patient's medical condition, reviewing records for quality assurance or drug use evaluation programs, and providing information on a wide range of health issues are all part of the pharmacist's basic role. To effectively communicate with physicians, nurses, technicians, therapists, and others in health care requires an unwavering ability to deal with the language of the profession.

So of all the health professionals, pharmacists are perhaps in the greatest need of a clear understanding of medical terminology and an ability to "translate" it into lay language. As simple translators, pharmacists need to know not only the specific term for a diagnosis, but also how to express that meaning in terms the patient will understand.

Much more important, though, is the ability to serve as "interpreter" for patients and the health care community. While a translator converts one language to another, an interpreter must provide a broader understanding. The pharmacist, therefore, must not only translate a term from English to "medical" and back again, but he or she should catch the nuances of each language and interpret the context as well as the definition. Some patients may use medical terminology to "sound scientific" and hide their fear; the pharmacist should be able to discern such usage and reassure these patients. Other patients may know the literal definition of a term without understanding how it applies to them; the pharmacist then must clarify the explanation so the patient truly understands.

But becoming an interpreter is not the only reason a pharmacist might need to study medical terminology. A basic problem is that pharmacy education has changed drastically over the last few decades. The educational system in the 1950 s and 1960 s included more of the medical sciences than ever before that time, but much less emphasis was placed on therapeutics and pathophysiology than in later years. Pharmacists who graduated in those decades were not exposed to the same terminology as their younger colleagues. The emphasis on clinical knowledge during the 1980s and into the 1990s expanded that base significantly, but it was still incomplete. After all, the five or six years required to become a pharmacist is hardly sufficient time to learn all one needs to know about the pharmaceutical sciences, much less the rest of the medical sciences. Programs incorporating a strong therapeutic base still can only cover the most common diseases and procedures; there simply is not enough time to learn it all.

So those pharmacists who have been out of school for some time may now be discovering a weakness in medical terminology. Even those whose practices have focused on the dispensing functions are finding that they are no longer insulated from the patient or the rest of the health care community. Practice is changing; patients are changing; indeed, the entire health care system is changing. And a grasp of medical terminology is one of the tools pharmacists need if they are to change with it.

\section{Objectives}

The role of this text, then, is to provide the practicing pharmacist (or pharmacy student, with a little guidance) a sufficient basis in medical terminology so that he or she is able to understand most of the medical terms encountered in practice. To do that, the book approaches terminology through a study of the parts of words-the prefixes, roots, and suffixes that create the meanings attributed to the total term.

Pharmacists and pharmacy students should approach this book as a study tool. It is 
organized in a learning sequence and can be read from beginning to end by those wanting a full understanding of the terminology involved. Or the individual therapeutic chapters can be studied separately for those wishing to refine their knowledge in a specific area. Either way, however, readers should begin their study with the first five chapters, which form the base for the rest of the book. By the time the reader has completed this text, he or she should be able to do the following:

- Identify common prefixes, roots, and suffixes used in medical terms and provide their definitions.

- Identify the prefixes, roots, and suffixes in each of a list of selected medical terms and define each term from the meaning of its components.

- Describe the role of prefixes, roots, and suffixes used in medical terms and how selected ones alter the definition of the term.

- Explain how combining forms differ from roots and how they are used in forming medical terms.

- Provide the appropriate medical term for each of a list of definitions by synthesizing the terms from the appropriate components.

- Describe how the definition of each term in a selected list is derived from the various possible combinations of components.

- Describe the anatomical composition of each of the discussed organ systems and explain how the relevant medical terms are developed.

- List the major procedures and therapeutic modalities used in the treatment of selected diseases for each organ system or therapeutic category covered.

A secondary role of this book is for continuing pharmaceutical education. It was written as an educational tool for pharmacists, as well as for pharmacy students. Its intent in part, therefore, is to make pharmacists more effective in practice by helping them deal more effectively with patients and other health care providers. Thus, by its very nature it was designed to be a continuing education tool. Part of any education is self-assessment as the student progresses, and self-study questions are found in Appendix A. Separately from the book, readers may also receive a larger examination covering the material in larger sections. That examination is designed to provide continuing pharmaceutical education credit for those successfully completing the text. For information concerning such credit, readers are directed to the separate continuing education component.

Because this book is intended for both pharmacy students and pharmacists, it contains a wide range of medical terms that are encountered in pharmacy practice. Some terms, however, are specifically excluded. For example, brand and generic drug names are generally omitted, as are chemical terms. Those in or preparing for the pharmacy profession are recognized as society's drug experts; their entire training is directed toward that end. Gaps that may occur in their knowledge of medical terms are likely to be in areas other than drugs and chemicals.

Also omitted is a thorough discussion of medical therapeutics. Although most of the chapters in Part II are organized by body systems or therapeutic categories, the focus is on terminology. Numerous other texts are available for those who wish to study anatomy, physiology, biochemistry, pharmacotherapy, medical therapeutics, or other approaches to the science of health care. Admittedly, terminology is integral to such studies, and this book may serve as the base on which the reader can build. But the intent herein is to 
help the reader learn the basic skills in communicating about patients, diseases, and therapies-not the skills used in treating disease.

Whatever reasons the reader has for studying medical terminology, the authors have endeavored to make that study both interesting and useful. We exhort you to apply diligence and attention to be successful. 


\section{PART I}

\section{THE BASIS OF \\ MEDICAL TERMINOLOGY}




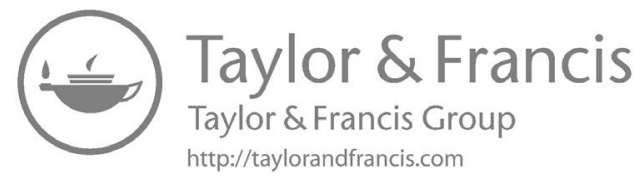




\section{Fundamentals of Medical Terms}

\section{Introduction}

Like every other specialized discipline, the practice of medicine has evolved its own language over the years, using terminology not found in the general vocabulary. An understanding of medical terminology requires two basic elements: (1) some knowledge of the body structure and functions and (2) familiarity with meanings of the prefixes, suffixes, and roots comprising medical terms.

Most medical terms are composed of roots or stems derived from Greek or Latin and used in combination with prefixes and suffixes. These language sources are used interchangeably, such as in the term appendicitis containing the Latin appendix and the Greek suffix -itis. Terms derived from Greek and Latin have the advantage of being precise and unchanging. They have the same meaning in all countries; therefore, medical terminology is a universal language.

The fundamental method for building a medical vocabulary consists of analyzing a word by identifying its root, suffix, and prefix. Most medical terms are derivative; that is, they consist of a combination of two or more roots or word elements rather than a single Greek or Latin word. The identification of a term through structural analysis involves determining the meaning of each of its components that will either reveal the exact definition of the word or convey its applied meaning.

$$
\text { Example: } \quad \begin{aligned}
\text { myopathy } & =\text { myo (root meaning "muscle") } \\
& + \text { pathy (suffix meaning "disease") }
\end{aligned}
$$

Some words are comprised of more than one root, each of which retains its basic meaning. Such words, referred to as compounds, are very commonly found in medical terminology.

$$
\begin{aligned}
& \text { Example: } \quad \text { osteoarthritis }=\text { inflammation of the bone joints } \\
& \text { osteo, = meaning bone (root) } \\
& \text { arthro, }=\text { meaning joint (root) } \\
& \text { itis, = meaning inflammation (suffix) }
\end{aligned}
$$

For some medical terms, both the Greek and Latin spellings have been adopted as acceptable forms, so the spelling of a root can vary from one term to another. It is 
imperative, therefore, that a medical dictionary be consulted to determine the correct spelling of unfamiliar words. Because an incorrect spelling can convey an inaccurate impression, diagnosis, condition, or procedure, phonetic spelling has no place in the medical field.

As spelling of a root can vary, so too can pronunciation. Pronunciation of medical terms can be difficult initially, since no rigid rules can be followed. In addition, some words may be acceptably pronounced in more than one way. Common usage prevails; discrepancies in pronouncing medical terms will be found even in the same location.

$$
\begin{aligned}
& \text { Example: } a b \text { do"men or } a b^{\prime \prime} \text { do men } \\
& \text { la } b^{\prime \prime} \text { o ra tory or la bor" a tory } \\
& d u^{\prime \prime} o \text { de' num or du od' e num } \\
& \text { bar bit" u rate or bar" bi tu' rate }
\end{aligned}
$$

. Although the pronunciations of a few key terms are provided in each chapter to help the reader grasp the basics of the spoken terms, pronunciation keys are not included for every term presented. After all, these pronunciations are available in all of the standard medical dictionaries, and every effort was made to keep this text to manageable proportions for the reader. Those pronunciations of which the reader is unsure should be determined from a medical dictionary. Repeated spoken use of the terms is the most helpful tool in acquiring mastery of expression.

The point of studying suffixes, roots, and prefixes is to refine the ability to analyze unknown words and derive an accurate meaning. How to go about that may initially seem backwards, but the definition of a term or its applied meaning can usually best be determined by beginning the analysis with the suffix and proceeding to the root and then the prefix. The reason is that the suffix often gives the general context, part of speech, or activity involved; the root then may determine the part of the body, the basic action, or other specific application or meaning. The prefix usually provides restriction or modification of the understanding derived from the suffixes and roots.

\section{Suffixes}

True suffixes consist of one or more syllables added to root words to modify the meaning and/or to indicate the part of speech-that the completed word is either a preposition or an adverb. Many endings, however, are nouns or adjectives added to a root to form a compound word. Such nouns and adjectives are not true suffixes; they are combinations of true suffixes and roots and may be referred to as combining forms or pseudosuffixes.

$\begin{array}{llll}\text { Example: } & - \text { gloss } & \text { (tongue) } & \text { Root } \\ & -a l & \text { (related to) } & \text { True suffix } \\ & - \text { glossal } & \text { (related to the tongue) } & \text { Pseudosuffix }\end{array}$

These compound endings may then be added to other prefixes or roots, as in the word hypoglossal. Because words are built of prefixes, roots, and suffixes, reasons arise to include multiple restrictions or modifications on the root, so a single word may contain more than one suffix at a time. 
Table 1.1-Suffixes: Commonly Used Word Endings

\begin{tabular}{|c|c|c|c|c|c|}
\hline Suffix & Meaning & Example & Suffix & Meaning & Example \\
\hline $\begin{array}{l}\text {-able } \\
\text {-ible } \\
\text {-ile }\end{array}$ & ability & $\begin{array}{l}\text { palatable } \\
\text { flexible } \\
\text { fragile }\end{array}$ & $\begin{array}{l}\text {-eal } \\
\text {-eous }\end{array}$ & $\begin{array}{l}\text { of that kind, } \\
\text { pertaining } \\
\text { to }\end{array}$ & $\begin{array}{l}\text { popliteal } \\
\text { calcaneous }\end{array}$ \\
\hline & & & -ose & & adipose \\
\hline $\begin{array}{l}-a c \\
-a l\end{array}$ & $\begin{array}{l}\text { related to, } \\
\text { concerning, }\end{array}$ & $\begin{array}{l}\text { cardiac } \\
\text { abdominal }\end{array}$ & -ous & & mucinous \\
\hline -an & $\begin{array}{l}\text { pertaining } \\
\text { to }\end{array}$ & ovarian & $\begin{array}{l}\text {-esis } \\
\text {-ia }\end{array}$ & $\begin{array}{l}\text { condition, } \\
\text { state }\end{array}$ & $\begin{array}{l}\text { paresis } \\
\text { dysplasia }\end{array}$ \\
\hline -ar & & ocular & -iasis & & cholelithiasis \\
\hline -ary & & papillary & $-i d$ & & flaccid \\
\hline$-i c$ & & pyogenic & $-i s m$ & & catabolism \\
\hline -ical & & practical & $-i t y$ & & hyperacidity \\
\hline -ory & & sensory & -osis & & diverticulosis \\
\hline- tic & & orthodontic & $\begin{array}{l}\text {-tia } \\
\text {-tion }\end{array}$ & & $\begin{array}{l}\text { procidentia } \\
\text { malabsorption }\end{array}$ \\
\hline $\begin{array}{l}\text {-ate } \\
\text {-esis }\end{array}$ & action & $\begin{array}{l}\text { pulsate } \\
\text { enuresis }\end{array}$ & $-y$ & & gouty \\
\hline -ure & & measure & $\begin{array}{l}\text {-cle } \\
\text {-cule }\end{array}$ & small & $\begin{array}{l}\text { corpuscle } \\
\text { molecule }\end{array}$ \\
\hline -form & $\begin{array}{l}\text { resem- } \\
\text { blance, }\end{array}$ & veriform & $\begin{array}{l}\text {-culum } \\
\text {-culus }\end{array}$ & & $\begin{array}{l}\text { tuberculum } \\
\text { ductulus }\end{array}$ \\
\hline -oid & like & fibroid & $\begin{array}{l}\text {-et } \\
\text {-ium }\end{array}$ & & $\begin{array}{l}\text { pipet } \\
\text { endocardium }\end{array}$ \\
\hline$-e$ & agent & lactagogue & -ole & & arteriole \\
\hline & & inhaler & -olum & & hordeolum \\
\hline -ician & & physician & -olus & & bolus \\
\hline -ist & & urologist & & & \\
\hline -or & & levator & -ious & $\begin{array}{l}\text { capable of, } \\
\text { causing }\end{array}$ & infectious \\
\hline
\end{tabular}

Table 1.2-Suffixes: Symptomatic and Miscellaneous

\begin{tabular}{lll|lll}
\hline Suffix & Meaning & Example & Suffix & Meaning & Example \\
\hline -agogue & $\begin{array}{l}\text { producer, } \\
\text { leader }\end{array}$ & sialagogue & -atresia & $\begin{array}{l}\text { abnormal } \\
\text { closure }\end{array}$ & proctatresia \\
-agra & attack, sei- & podagra & -cele & $\begin{array}{l}\text { hernia, } \\
\text { swelling }\end{array}$ & hydrocele \\
-algia & pain & neuralgia & -chesia & $\begin{array}{l}\text { discharge } \\
\text { of foreign }\end{array}$ & hechatochezia \\
-aphia & touch & amblyaphia & -chezia & substance & \\
-ase & enzyme & lipase & -cide & destroy, kill germicide
\end{tabular}




\begin{tabular}{|c|c|c|c|c|c|}
\hline Suffix & Meaning & Example & Suffix & Meaning & Example \\
\hline -cleisis & closure & enterocleisis & $-\log y$ & $\begin{array}{l}\text { science/ } \\
\text { study of }\end{array}$ & cardiology \\
\hline -didymus & cojoined & atlodidymus & & & \\
\hline -dymus & wwin & triopodymus & -lysis & $\begin{array}{l}\text { dissolving, } \\
\text { reduction }\end{array}$ & hemolysis \\
\hline -dynia & pain & pleurodynia & -mentia & mind & dementia \\
\hline -ectasis & $\begin{array}{l}\text { expansion, } \\
\text { dilatation }\end{array}$ & angiectasis & $\begin{array}{l}\text {-metry } \\
\text {-meter }\end{array}$ & $\begin{array}{l}\text { measure/ } \\
\text { instrument }\end{array}$ & $\begin{array}{l}\text { optometry } \\
\text { craniometer }\end{array}$ \\
\hline -ema & $\begin{array}{l}\text { swelling, } \\
\text { distention }\end{array}$ & emphysema & nomy & law & taxonomy \\
\hline -emia & blood & septicemia & -0 & $\begin{array}{l}\text { alcohol, } \\
\text { phenol }\end{array}$ & ethanol \\
\hline meren & bear, carry & efferent & oma & tumor & carcinoma \\
\hline - ferous & $\begin{array}{l}\text { to bear, pro- } \\
\text { duce }\end{array}$ & ossirious & -opia & Slight derect & amblyopia \\
\hline -luge & $\begin{array}{l}\text { expel, crive } \\
\text { away }\end{array}$ & centrifuge & -opsia & $\begin{array}{l}\text { condition of } \\
\text { vision }\end{array}$ & xanthopsia \\
\hline -genic & $\begin{array}{l}\text { producing, } \\
\text { origination }\end{array}$ & bronchogenio & $-o s e$ & sugar & glucose \\
\hline -iasis & $\begin{array}{l}\text { presencel } \\
\text { fomation of }\end{array}$ & nephrolithasis & -osis & $\begin{array}{l}\text { abnomal } \\
\text { condition }\end{array}$ & dematosis \\
\hline -id & $\begin{array}{l}\text { secondary } \\
\text { lesion }\end{array}$ & tuberculid & -pagus & $\begin{array}{l}\text { to } \text { asten to } \\
\text { gether }\end{array}$ & diplopagus \\
\hline & & & -pathy & disease & myelopathy \\
\hline -ide & $\begin{array}{l}\text { a binary } \\
\text { compound }\end{array}$ & chloride & -penia & $\begin{array}{l}\text { lack, deri- } \\
\text { ciency }\end{array}$ & leukoperuia \\
\hline -ine & $\begin{array}{l}\text { a nitroge- } \\
\text { nous } \\
\text { compound }\end{array}$ & morphine & -phagia & $\begin{array}{l}\text { to eat, swal- } \\
\text { low }\end{array}$ & dysphagia \\
\hline -ite & division & metabolite & -phasia & speech & dysphasia \\
\hline -itis & \multicolumn{2}{|c|}{ inflammation arthritis } & -philia & $\begin{array}{l}\text { to love, to } \\
\text { crave }\end{array}$ & hemophilia \\
\hline lemma & $\begin{array}{l}\text { sheath, en- } \\
\text { velope }\end{array}$ & neurilemma & -phobia & ro fear & photophobia \\
\hline
\end{tabular}




\begin{tabular}{|c|c|c|c|c|c|}
\hline Suffix & Meaning & Example & Suffix & Meaning & Example \\
\hline -plasia & $\begin{array}{l}\text { develop- } \\
\text { ment }\end{array}$ & hyperplasia & -stasis & $\begin{array}{l}\text { at a stand- } \\
\text { still }\end{array}$ & hemostasis \\
\hline -plegia & paralysis & hemiplegia & -staxis & hemorrhage & epistaxis \\
\hline -pnea & breathing & dyspnea & -taxis & $\begin{array}{l}\text { involuntary } \\
\text { response to }\end{array}$ & rheostaxis \\
\hline -poiesis & $\begin{array}{l}\text { make, pro- } \\
\text { duce }\end{array}$ & hemopoiesis & & stimuli & \\
\hline -ptosis & to fall & blepharoptosis & -thyma & $\begin{array}{l}\text { condition of } \\
\text { mind }\end{array}$ & cyclothymic \\
\hline -rrhagia & $\begin{array}{l}\text { excessive } \\
\text { discharge }\end{array}$ & menorrhagia & -tome & $\begin{array}{l}\text { cutting in- } \\
\text { strument }\end{array}$ & osteotome \\
\hline $\begin{array}{l}\text {-rrhea } \\
\text {-rrhexis }\end{array}$ & $\begin{array}{l}\text { flow } \\
\text { rupture }\end{array}$ & $\begin{array}{l}\text { leukorrhea } \\
\text { cardiorrhexis }\end{array}$ & -tonia & $\begin{array}{l}\text { streiching, } \\
\text { causing ten- } \\
\text { sion }\end{array}$ & hypertonia \\
\hline -scope & $\begin{array}{l}\text { instrument } \\
\text { for viewing }\end{array}$ & bronchoscope & -ule & small & tubule \\
\hline -spasm & $\begin{array}{l}\text { involuntary } \\
\text { contraction }\end{array}$ & enterospasm & -uria & $\begin{array}{l}\text { condition of } \\
\text { the urine }\end{array}$ & glycosuria \\
\hline -stalsis & constriction & peristalsis & $\begin{array}{l}\text {-vert } \\
\text {-vorous }\end{array}$ & turn & divert \\
\hline
\end{tabular}

Table 1.3-Suffixes: Surgical/Diagnostic Procedures

\begin{tabular}{|c|c|c|c|c|c|}
\hline Suffix & Meaning & Example & Suffix & Meaning & Example \\
\hline -centesis & $\begin{array}{l}\text { puncture, } \\
\text { aspiration }\end{array}$ & thoracentesis & -ostomy & $\begin{array}{l}\text { form an } \\
\text { opening }\end{array}$ & colostomy \\
\hline -clasis & fracture & osteoclasis & -otomy & incision into & laparotomy \\
\hline -desis & fusion & arthrodesis & -pexy & $\begin{array}{l}\text { fixation, } \\
\text { suspension }\end{array}$ & hysteropexy \\
\hline -ectomy & excision & gastrectomy & & & \\
\hline -lysis & freeing & enterolysis & -plasty & repair & blepharoplasty \\
\hline -ography & process & roentgenography & -rrhaphy & suture & herniorrhaphy \\
\hline -oscopy & look within & cystoscopy & -tripsy & $\begin{array}{l}\text { crushing, } \\
\text { friction }\end{array}$ & lithotripsy \\
\hline
\end{tabular}


Table 1.1 includes some commonly used word endings, along with their meanings and examples of their use in medical terms. Tables 1.2 and 1.3 list suffix endings denoting physiology, symptoms, and procedures. A study of true suffixes apart from their association with specific use-as, for example, those dealing with diagnostic terms (Chapter 3) -is difficult and necessitates repetition. For this reason, all of the true suffixes are introduced in this chapter and then presented again in specific areas to reinforce their common usage. Their sheer number makes learning these suffixes a daunting task, but careful review and repetition of these suffixes in a large number of terms simplifies the problem. In addition, the tables are useful for reference long after their original study.

\section{Roots}

The word root or stem is the fundamental or elementary part of the word that conveys its primary notion or significance. Modification of the basic meaning is then made by the addition of prefixes, suffixes, or other roots. The root should not be confused with a prenix or suffix, regardless of the position of the root within a word. Prefixes come at the beginning and suffixes at the end of a word, but a root can appear anywhere, including before or after another root. The roots (since there may be more than one) give the word its primary meaning; prefixes or suffixes, however, serve to modify that meaning. Those roots used in medical terminology generally indicate an organ or part of the body.

The term combining forms is often encountered in the study of medical terminology. A combining form of a root is created by the addition of a vowel, usually $o$, to the word root. This is done primarily for ease in pronunciation. These are, therefore, convenience forms and do not influence the meaning of a word root.

$\begin{array}{lll}\text { Example: } & \text { (Combining Form) } & \text { gastro- } \\ & \text { (Root) } & \text { gastr } \\ \text { (Medical Terms) } & \text { gastr(o)dynia } \\ & \text { gastralgia } \\ & \text { gastritis }\end{array}$

Some roots end in vowels, so frequently there is no need to add a vowel to these roots to create a combining form. Further, the addition of a vowel would place two vowels in succession. Thus, a vowel is usually not added if the word root ends in a vowel and two vowels would be in sequence.

$\begin{array}{lll}\text { Example: } & \text { celio- } & \text { (Root meaning abdomen) } \\ \text {-oma } & \text { (Suffix meaning tumor) } \\ & \text { celioma } & \text { (tumor of the abdomen) }\end{array}$

A medical dictionary should be consulted whenever correct spelling is in question.

Most of the medical terms in this text are categorized by body system or other therapeutic category in Part II. The list in Table 1.4, however, contains many commonly used roots or combining forms that do not readily fall into the body system classifications or that apply to more than one. Since the meaning of a word can be determined by 
Table 1.4-Roots: Combining Forms, Miscellaneous

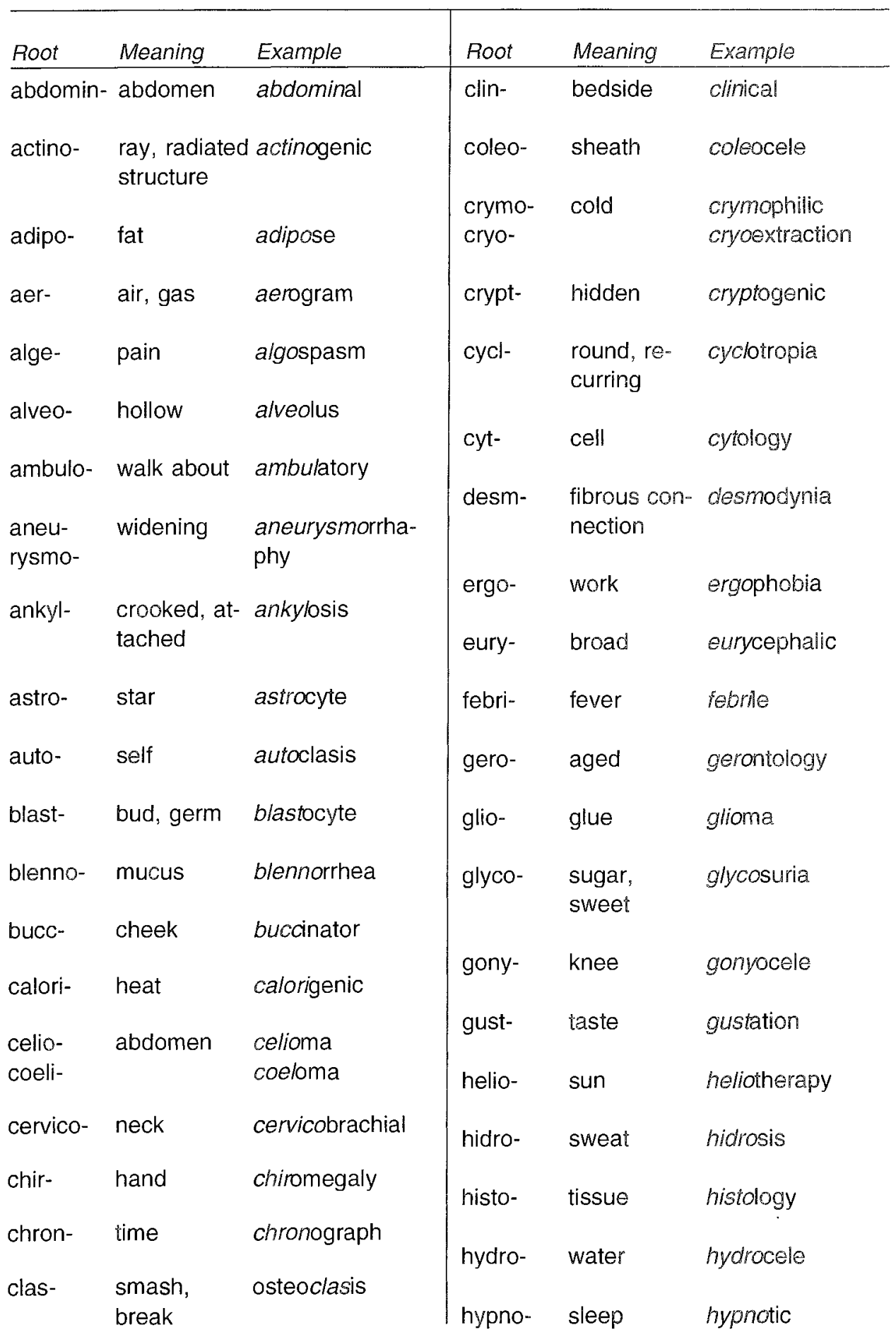




\begin{tabular}{|c|c|c|c|c|c|}
\hline Root & Meaning & Example & Roor & Meaning & Example \\
\hline iatro- & $\begin{array}{l}\text { medicine, } \\
\text { physician }\end{array}$ & iatrogenic & not- & the back & notalgia \\
\hline ictero- & jaundice & icterogenic & oligo- & few, little & oliguria \\
\hline iso- & equal & isotonic & omo= & shoulder & omodynia \\
\hline kinesio- & movement & kinesiology & omphalo- & umbilicus & omphalotomy \\
\hline lapar- & loin, flank & laparotomy & oneir- & dream & oneirism \\
\hline lepto. & slender, thin & leptodermic & oxy- & sharp, keen & oxycephalic \\
\hline lip- & fat & lipoma & pachy- & thick & pachyonchia \\
\hline litho- & stone & lithogenesis & paleo- & old & paleogenetic \\
\hline lyso- & dissolving & Iysogenic & pan- & all & panarthritis \\
\hline macro- & large, long & macronychia & $\begin{array}{l}\text { papillo- } \\
\text { papulo- }\end{array}$ & pustule & $\begin{array}{l}\text { papilloma } \\
\text { papulosquamous }\end{array}$ \\
\hline mal- & ill, bad, poor & malabsorption & patho- & disease & pathology \\
\hline megalo- & large & megalocyte & pedia- & child & pediatrics \\
\hline mero- & part & merotomy & pedo- & foot & pedograph \\
\hline micro- & small & microgram & pero- & deformed & perobrachius \\
\hline mio- & less, smaller & miosis & phago- & devour, eat & phagocyte \\
\hline morpho- & form & amorphous & phanero- & $\begin{array}{l}\text { appear, visi- } \\
\text { ble }\end{array}$ & phanerosis \\
\hline muco- & mucus & mucopurulent & photo- & light & photophobia \\
\hline $\begin{array}{l}\text { myco- } \\
\text { myx- }\end{array}$ & $\begin{array}{l}\text { fungi } \\
\text { mucus }\end{array}$ & $\begin{array}{l}\text { mycology } \\
\text { myxedema }\end{array}$ & phren- & $\begin{array}{l}\text { mind, dia- } \\
\text { phragm }\end{array}$ & phrenic \\
\hline necro- & death & necrosis & phthisio- & $\begin{array}{l}\text { wasting, at- } \\
\text { rophy }\end{array}$ & phihisiology \\
\hline $\begin{array}{l}\text { nocto- } \\
\text { nycto- }\end{array}$ & night & $\begin{array}{l}\text { nocturia } \\
\text { nyctophilia }\end{array}$ & phyco- & seaweed & phycobilins \\
\hline noso- & disease & nosopoietic & $\begin{array}{l}\text { physio- } \\
\text { phyt- }\end{array}$ & $\begin{array}{l}\text { nature } \\
\text { olant }\end{array}$ & $\begin{array}{l}\text { physiology } \\
\text { hematophyte }\end{array}$ \\
\hline
\end{tabular}




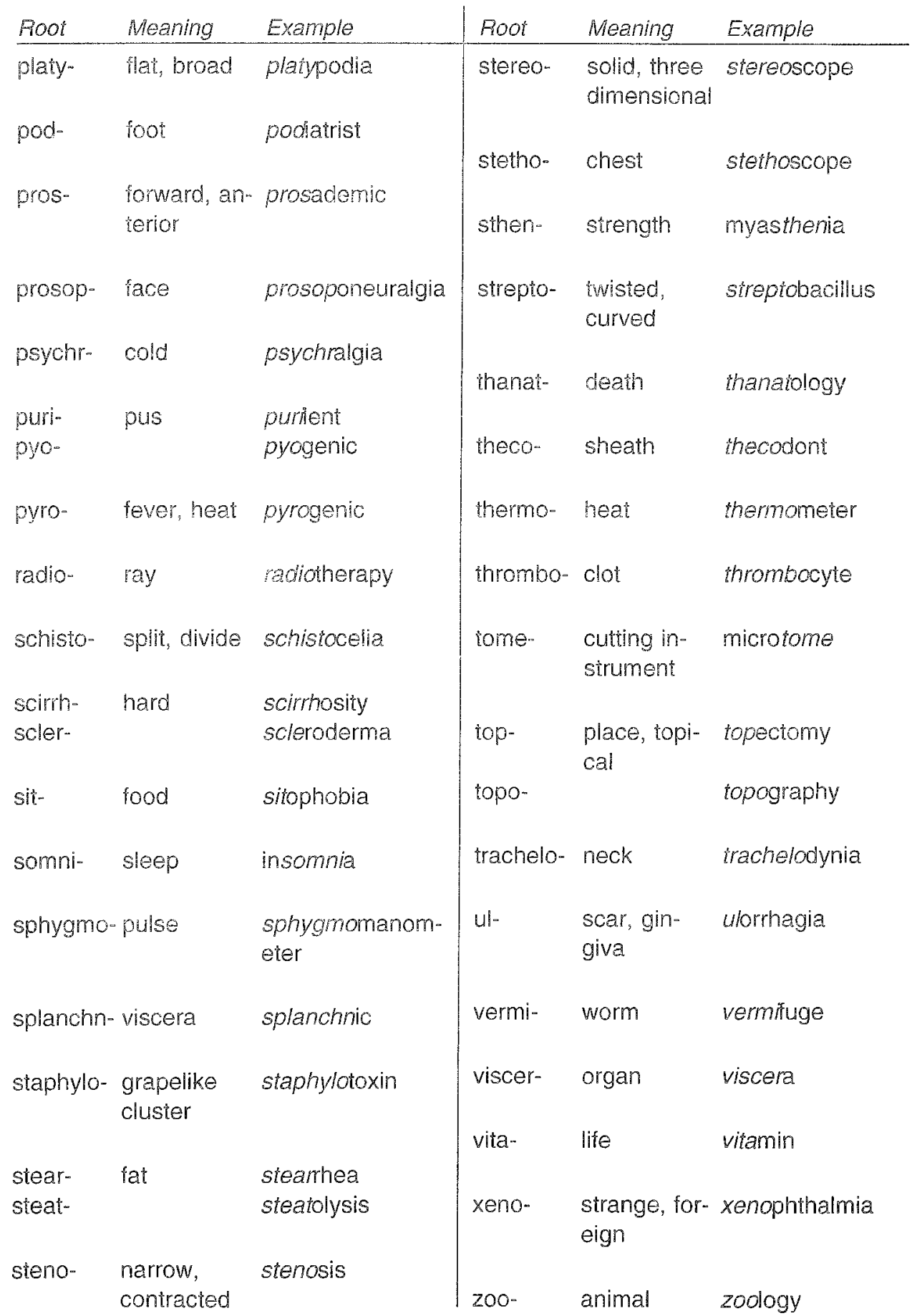


knowledge of its basic parts, these examples should illustrate the value of learning root words as a basis for understanding medical terminology.

\section{Prefixes}

Prefixes are the most frequently used elements in the formation of medical terms. Most prefixes are commonly used in everyday language and are not unique to medical terminology, so those wanting to learn or improve their mastery of medical terminology have a sound basis on which to build.

Prefixes may be adjectives, adverbs, or prepositions that are used to indicate various relationships or conditions of the root word. Most prefixes have a final vowel that is deleted if the following root or stem begins with a vowel.

Since prefixes originate from both Latin and Greek, two different prefixes may have the same meaning. For example, the prefixes poster-and retro-both indicate "behind," as in the terms posterior and retrograde. Conversely, multiple meanings may be associated with a single prefix because of multiple sources for the prefix; meta-, for example, can mean both "over" and "after change."

True prefixes are distinguished from roots in that they serve only to modify the meaning of the root and have no significance alone. Roots that are used at the beginning of words are not considered to be true prefixes.

$\begin{array}{lll}\text { Example: } & \begin{array}{l}\text { Prefixes } \\ \text { hypertrophy } \\ \text { bradycardia }\end{array} & \begin{array}{l}\text { Roots } \\ \text { hepatomegaly } \\ \text { osteomyelitis }\end{array}\end{array}$

The prefixes listed in Tables 1.5 through 1.8 have been grouped according to the type of relationship or conditions that they identify. The examples serve to illustrate how prefixes are joined to root words.

\section{Body as a Whole}

Medical terms describing position or direction relative to the body are expressed in terms of the "anatomical position": the human body standing erect, arms at the sides and the palms of the hands turned forward. This reflects the anterior (anter/o) or front side, also called the ventral or belly side. The combining form for posterior is poster/ $o$, meaning "back"; dorsal (dors/o) also refers to the back side of an organism. The combining form for the side is later/o. Unilateral (uni $=$ one) would denote one side, while bilateral $(b i=$ two $)$ means two or both sides. Medial pertains to the middle. Other combining forms referring to locations on the body include super-, meaning superior (e.g., superficial); dist-, meaning far or distant (e.g., distal); proxim-, meaning near (e.g., proximal); caudo-, meaning tail or lower part (e.g., caudal); and cephal-, meaning head (e.g., cephalad).

The abdomen is divided into nine anatomic regions. The right and left hypochondriac regions are those lying beneath (hypo-) the ribs, although the term also describes a person who is overly concerned with health and may imagine illness (named for the region of the body that was thought to be the seat of the disease). Between the hypochondria is 
Table 1.5-Prefixes: Location, Direction, Tendency

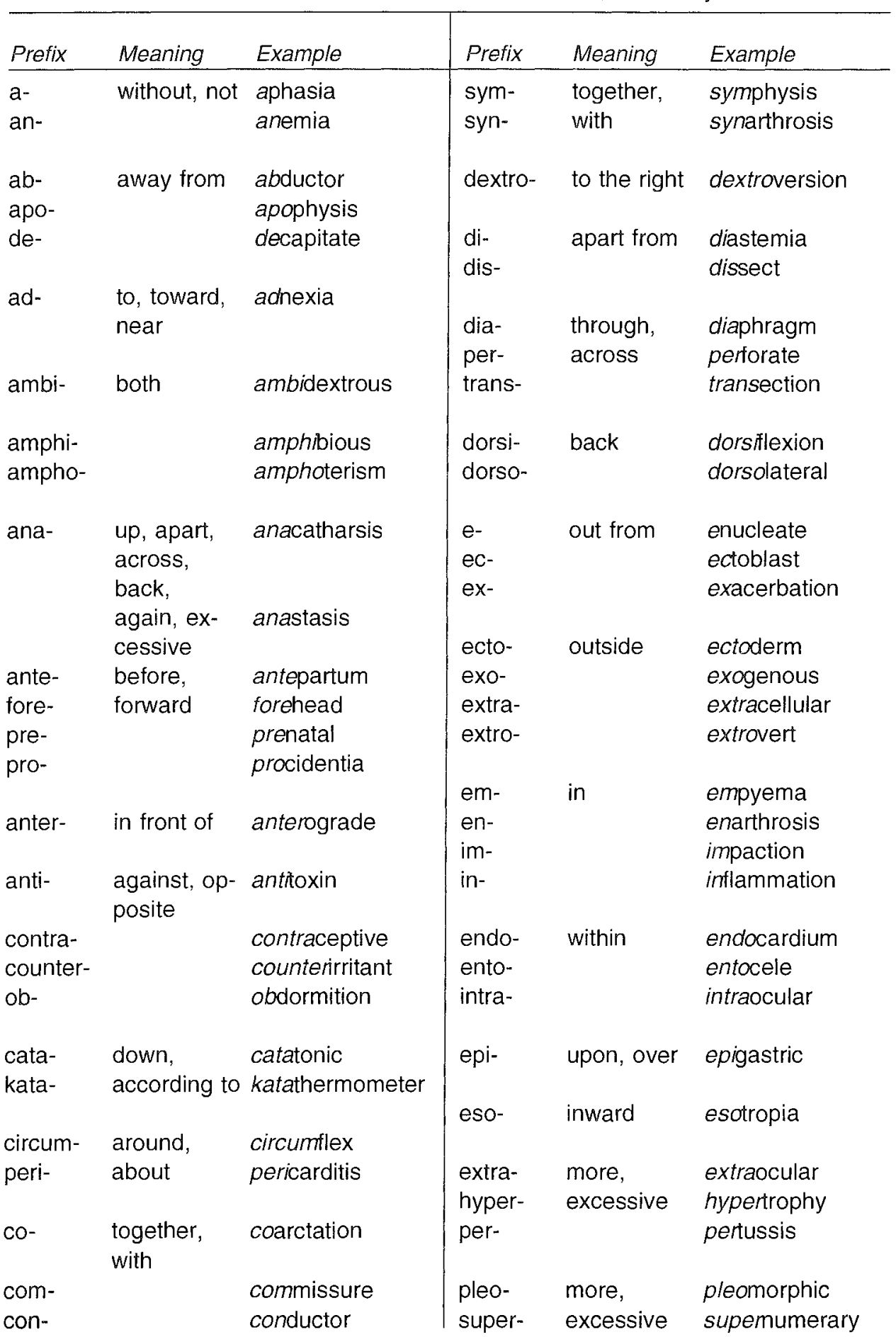




\begin{tabular}{|c|c|c|c|c|c|}
\hline Prefix & Meaning & Example & Prefix & Meaning & Example \\
\hline gen- & $\begin{array}{l}\text { producing; } \\
\text { coming to } \\
\text { be }\end{array}$ & genetics & $\begin{array}{l}\text { medi- } \\
\text { mes- } \\
\text { mid- }\end{array}$ & $\begin{array}{l}\text { in the } \\
\text { middle }\end{array}$ & $\begin{array}{l}\text { medial } \\
\text { nesocephalic } \\
\text { miobrain }\end{array}$ \\
\hline nomo- & same & homogeneous & meta- & $\begin{array}{l}\text { over, atter, } \\
\text { change }\end{array}$ & metastasis \\
\hline hyper- & above, over & hypenophy & & & \\
\hline $\begin{array}{l}\text { nypo. } \\
\text { intra. }\end{array}$ & $\begin{array}{l}\text { below, } \\
\text { under, }\end{array}$ & $\begin{array}{l}\text { hypotension } \\
\text { intrabbita! }\end{array}$ & $\begin{array}{l}\text { opisho- } \\
\text { poster- }\end{array}$ & $\begin{array}{l}\text { behind, } \\
\text { backward }\end{array}$ & $\begin{array}{l}\text { opishotic } \\
\text { posteromedian }\end{array}$ \\
\hline sub- & $\begin{array}{l}\text { beneath, } \\
\text { less, defi- } \\
\text { cient }\end{array}$ & subculaneous & $\begin{array}{l}\text { pere- } \\
\text { post- }\end{array}$ & $\begin{array}{l}\text { bosice, near } \\
\text { ater, behind }\end{array}$ & $\begin{array}{l}\text { parcentesis } \\
\text { posparum }\end{array}$ \\
\hline $\begin{array}{l}\text { im- } \\
\text { in- } \\
\text { ir- }\end{array}$ & not & $\begin{array}{l}\text { miscible } \\
\text { inaniculete } \\
\text { meducible }\end{array}$ & $\begin{array}{l}\text { primi- } \\
\text { prot- }\end{array}$ & first & $\begin{array}{l}\text { primpara } \\
\text { protodem }\end{array}$ \\
\hline non- & & nontoxic & & again & rehabiliation \\
\hline inter- & between & $\begin{array}{l}\text { unconscious } \\
\text { intercostal }\end{array}$ & retro- & $\begin{array}{l}\text { beckwerd, } \\
\text { behind }\end{array}$ & retrograde \\
\hline intro- & into & introversion & $\begin{array}{l}\text { Super- } \\
\text { supre- }\end{array}$ & $\begin{array}{l}\text { above, } \\
\text { excessive }\end{array}$ & $\begin{array}{l}\text { supematant } \\
\text { suprarenal }\end{array}$ \\
\hline $\begin{array}{l}\text { ipsi- } \\
\text { iso- }\end{array}$ & same, equal & $\begin{array}{l}\text { ioshateral } \\
\text { isometric }\end{array}$ & uttre- & & ufrasonic \\
\hline juxta- & near & juxtaposition & $\begin{array}{l}\text { tel- } \\
\text { tele- } \\
\text { telo- }\end{array}$ & $\begin{array}{l}\text { end, } \\
\text { distance }\end{array}$ & $\begin{array}{l}\text { relediastolic } \\
\text { teleopsia } \\
\text { telophase }\end{array}$ \\
\hline latero- & to the side & lateroflexion & & & \\
\hline levo- & to the left & levoversion & trans- & $\begin{array}{l}\text { across, } \\
\text { through }\end{array}$ & transplant \\
\hline sinistro- & to the left & sinistrocardia & ventro- & anterior & ventrofixation \\
\hline
\end{tabular}

the epigastric (epi = upon, gastr = stomach) region. The right and left lumbar regions are separated by the embillical (naval) region. Below are the ligyogastere and left and right inguimal or illac regions. Areas in the abdominal cavity are also divided by quadrants, designated as right upper quadrant (RUQ), left upper quadrant (LUQ), right lower quadrant (RLQ), and left lower quadrant (LL $(1)$.

The body has two principal body cavities designated as the verutral (front) and dorsal (back). The smaller dorsal cavity contains the cranial and spinal cavities. The ventral cavity contains the thoracic (chest) cavity, separated from the abdominal cavity by the diaphregm. Lowest is the pelvic cavity. The serous membrane lining these two (abdominopelvic) cavities is called the peritonem organs within the cavities are sometimes referred to as viscera. 
Table 1.6-Prefixes: Size, Condition, State

\begin{tabular}{|c|c|c|c|c|c|}
\hline Prefix & Meaning & Example & Prefix & Meaning & Example \\
\hline allo- & not normal & allotropic & ischio- & $\begin{array}{l}\text { suppress, } \\
\text { restrain }\end{array}$ & ischuria \\
\hline ambly- & dim, dull & amblyopia & $\begin{array}{l}\text { leio- } \\
\text { malaco- }\end{array}$ & $\begin{array}{l}\text { smooth } \\
\text { soft }\end{array}$ & $\begin{array}{l}\text { leiomyoma } \\
\text { malacia }\end{array}$ \\
\hline aniso- & $\begin{array}{l}\text { unequal, } \\
\text { dissimilar }\end{array}$ & anisocyosis & medulo- & marrow & medulloblastoma \\
\hline atel- & imperfect & atelectasis & mis- & $\begin{array}{l}\text { bad, wrong, } \\
\text { improper }\end{array}$ & miscarriage \\
\hline atreto- & $\begin{array}{l}\text { lack of } \\
\text { opening }\end{array}$ & atretocystia & mogi- & $\begin{array}{l}\text { painful, diffi- } \\
\text { cult }\end{array}$ & mogiphonia \\
\hline bio= & $\begin{array}{l}\text { relation to, } \\
\text { life }\end{array}$ & biology & myel- & marrow & myeloma \\
\hline $\begin{array}{l}\text { brachy- } \\
\text { brevi- }\end{array}$ & short & $\begin{array}{l}\text { brachycephalic } \\
\text { brevicollis }\end{array}$ & neutro- & neither & neutrophil \\
\hline brady- & slow & bradycardia & $\begin{array}{l}\text { poikilo- } \\
\text { poly- }\end{array}$ & $\begin{array}{l}\text { varied } \\
\text { many, much }\end{array}$ & $\begin{array}{l}\text { poikiloderma } \\
\text { polyuria }\end{array}$ \\
\hline caco- & bad, ill & cacogenic & presby- & old & presbyopia \\
\hline $\begin{array}{l}\text { cry- } \\
\text { dolicho- }\end{array}$ & $\begin{array}{l}\text { cold } \\
\text { long }\end{array}$ & $\begin{array}{l}\text { cryosurgery } \\
\text { dolichosigmoid }\end{array}$ & proto- & first, original & protovertebra \\
\hline dys- & $\begin{array}{l}\text { difficult, } \\
\text { painful }\end{array}$ & dyspnea & pseudo- & false & $\begin{array}{l}\text { pseudopreg- } \\
\text { nancy }\end{array}$ \\
\hline eu- & well, easily, & euphoria & sclero- & hard & sclerosis \\
\hline & good & & scoli- & $\begin{array}{l}\text { curved, } \\
\text { crooked }\end{array}$ & scoliosis \\
\hline haplo- & $\begin{array}{l}\text { single, sim- } \\
\text { ple }\end{array}$ & haploid & tachy- & fast & tachycardia \\
\hline heter- & $\begin{array}{l}\text { different, } \\
\text { other }\end{array}$ & heterochylia & torsi- & twist & torsion \\
\hline holo- & entire & holography & trachy- & rough & trachyphonia \\
\hline $\begin{array}{l}\text { homeo- } \\
\text { homo- }\end{array}$ & like, similar & $\begin{array}{l}\text { homeostasis } \\
\text { homogeneous }\end{array}$ & varico- & $\begin{array}{l}\text { twisted, } \\
\text { swollen }\end{array}$ & varicose \\
\hline & & & xero- & dry & xerocheilia \\
\hline
\end{tabular}


Table 1.7-Prefixes: Number, Measurement

\begin{tabular}{|c|c|c|c|c|c|}
\hline Prefix & Meaning & Example & Prefix & Meaning & Example \\
\hline $\begin{array}{l}\text { mono- } \\
\text { uni- }\end{array}$ & one & $\begin{array}{l}\text { monocyte } \\
\text { unilateral }\end{array}$ & deca- & ten & decameter \\
\hline $\begin{array}{l}\text { bi- } \\
\text { bin- }\end{array}$ & two, twice & $\begin{array}{l}\text { brurcation } \\
\text { binaural }\end{array}$ & micro- & $\begin{array}{l}\text { one one- } \\
\text { millionth }\end{array}$ & microgram \\
\hline $\begin{array}{l}\text { di- } \\
\text { diplo- } \\
\text { dis- }\end{array}$ & & $\begin{array}{l}\text { dicephalus } \\
\text { diplococcus } \\
\text { dismutase }\end{array}$ & milli- & $\begin{array}{l}\text { one one- } \\
\text { thousandth }\end{array}$ & milliliter \\
\hline $\begin{array}{l}\text { ter- } \\
\text { tri- }\end{array}$ & three, third & $\begin{array}{l}\text { tertiary } \\
\text { triceps }\end{array}$ & centi- & $\begin{array}{l}\text { one one- } \\
\text { hundredth }\end{array}$ & centimeter \\
\hline quad- & four & quadruplet & deci- & one tenth & decigram \\
\hline tetra- & & tetraplegia & hecto- & hundred & hectoliter \\
\hline $\begin{array}{l}\text { penta- } \\
\text { quinqu- }\end{array}$ & five & $\begin{array}{l}\text { pentavalent } \\
\text { quinquevalent }\end{array}$ & kilo- & thousand & kilogram \\
\hline quinti- & & quintipara & $\begin{array}{l}\text { demi- } \\
\text { hemi- }\end{array}$ & half & $\begin{array}{l}\text { demilune } \\
\text { hemicardia }\end{array}$ \\
\hline $\begin{array}{l}\text { hex- } \\
\text { sex- }\end{array}$ & $\operatorname{six}$ & $\begin{array}{l}\text { hexasaccharide } \\
\text { sextuplet }\end{array}$ & semi- & & semiconscious \\
\hline $\begin{array}{l}\text { hept- } \\
\text { sept- }\end{array}$ & seven & $\begin{array}{l}\text { heptachromic } \\
\text { septipara }\end{array}$ & $\begin{array}{l}\text { ambi- } \\
\text { amphi- } \\
\text { ampho- }\end{array}$ & both & $\begin{array}{l}\text { ambidextrous } \\
\text { amphibious } \\
\text { amphoteric }\end{array}$ \\
\hline octa- & eight & octagonal & $\begin{array}{l}\text { multi- } \\
\text { poly- }\end{array}$ & many & $\begin{array}{l}\text { multipara } \\
\text { polychromatic }\end{array}$ \\
\hline nona- & nine & nonan & & & \\
\hline
\end{tabular}

Table 1.8-Prefixes: Color

\begin{tabular}{|c|c|c|c|c|c|}
\hline Prefix & Meaning & Example & Prefix & Meaning & Example \\
\hline chroma- & color & chromatography & $\begin{array}{l}\text { ciner- } \\
\text { glauc- }\end{array}$ & gray & $\begin{array}{l}\text { cineritious } \\
\text { glaucoma }\end{array}$ \\
\hline $\begin{array}{l}\text { alb- } \\
\text { albumin- }\end{array}$ & white & $\begin{array}{l}\text { albinuria } \\
\text { albuminuretic }\end{array}$ & polio- & & poliomyelitis \\
\hline leuk- & & leukemia & $\begin{array}{l}\text { cirrh- } \\
\text { flav- }\end{array}$ & yellow & $\begin{array}{l}\text { cirrhosis } \\
\text { flavoprotein }\end{array}$ \\
\hline amaur- & dark & amaurosis & $\begin{array}{l}\text { lute- } \\
\text { xanth- }\end{array}$ & & $\begin{array}{l}\text { lutein } \\
\text { xanthoma }\end{array}$ \\
\hline $\begin{array}{l}\text { chlor- } \\
\text { verdin- }\end{array}$ & green & $\begin{array}{l}\text { chloranemia } \\
\text { verdohemoglobin }\end{array}$ & & & \\
\hline
\end{tabular}




\begin{tabular}{lll|lll} 
Prefix & Meaning & Example & Prefix & Meaning & Example \\
\hline cyano- & blue & cyanomycosis & $\begin{array}{l}\text { melan- } \\
\text { nigro- }\end{array}$ & black & $\begin{array}{l}\text { melanoma } \\
\text { nigrosine }\end{array}$ \\
$\begin{array}{l}\text { erythr- } \\
\text { rube- }\end{array}$ & red & $\begin{array}{l}\text { erythrocyte } \\
\text { rubella }\end{array}$ & purpur- & purple & purpura
\end{tabular}

\section{Glossary}

anterior-front; ventral

caudal-pertaining to the tail

cephalic - cranial; referring to the region of the head

diaphragm-muscle separating the thoracic and abdominal cavities

distal-far from the beginning or attachment of a structure

dorsal-posterior; back

epigastric-region above the stomach

hypochondriac-two upper regions of the body, located below the cartilage of the ribs

hypogastric - referring to the lower middle region of the body

inguinal-regions near the groin, also known as the iliac regions located near the upper hip bone

lateral-pertaining to the side

LLQ-region of the body containing the left ovary, fallopian tube, and ureter and part of the intestines

lumbar-regions of the body near the waist

LUQ - region of the body containing the stomach, spleen, and parts of the liver, pancreas, and intestines

medial-pertaining to the middle plane of the body

peritoneum-membrane that surrounds the organs in the abdominopelvic region of the body

posterior-back; dorsal

proximal-near the beginning or attachment of a structure

RLQ-region of the body containing the appendix, right ovary, fallopian tube, ureter, and part of the intestines

RUQ-region of the body containing the gallbladder and parts of the liver, pancreas, and intestines

superficial - on or near the surface

umbilical-region of the navel or umbilicus

ventral-anterior; front 


\section{BIBLIOGRAPHY}

American Medical Association. Physician's Current Procedural Terminology. Chicago, Illinois, 1996

Balch, James F. and Balch, Phyllis A. Prescriptions for Nutritional Healing. Avery Publishing Group Inc., Garden City Park, NY, 1990

Dorland's Illustrated Medical Dictionary. 28th edition. W. B. Saunders Publishing Company, Philadelphia PA, 1994

Eisenberg, Myron G. Dictionary of Rehabilitation. Springer Publishing Company, Inc., New York NY, 1995

Firkin, Barry G. and Whitworth, J. A. Dictionary of Medical Eponyms, 2nd edition. Parthenon Publishing Group, New York NY, 1995

Harrison's Principles of Internal Medicine, 12th edition. McGraw-Hill Book Company, New York NY, 1991

Holt, Robert J. and Stanaszek, Walter F. The Medical WordBook. H \& S Scientific Publishers, Oklahoma City, Oklahoma, 1994

Marti, James E. Alternative Health and Medicine Encyclopedia. Visible Ink Press, Detroit, Michigan, 1995

Taber's Cyclopedic Medical Dictionary. 18th edition. F. A. Davis Company, Philadelphia, Pennsylvania, 1997

Thibodeau, Gary A. Anatomy and Physiology. C. V. Mosby Company, St. Louis MO, 1993

Young, Lloyd Y. and Koda-Kimble, Mary A. Applied Therapeutics: The Clinical Use of Drugs. 6th edition. Applied Therapeutics, Inc., Vancouver, WA, 1995. 